\title{
Analysis of Class 1 Integrons and Antibiotic Resistance Genes in Pseudomonas aeruginosa Strains from Benin City, Nigeria
}

\author{
*ISICHEI-UKAH, BO; ENABULELE, OI
}

\author{
Department of Microbiology, Faculty of Life Sciences, University of Benin, P.M.B. 1154, Benin City, Nigeria
}

"Corresponding Author Email: brenda.isichei@uniben.edu

\begin{abstract}
The presence of integrons and antibiotic resistance genes in the genome of Pseudomonas aeruginosa pose a serious problem in the treatment and control of infections caused by this pathogen in hospitals. This study was carried to analyse the presence of class 1 integrons and some antibiotic resistance genes on selected clinical and environmental strains of Pseudomonas aeruginosa. A total of 120 strains were employed for this study. The strains were confirmed using molecular method and species-specific primers targeting the $16 \mathrm{~S}$ ribosomal ribonucleic acid (rRNA). Polymerase chain reaction (PCR) was used to detect the presence of class 1 integrons and resistance genes using appropriate primers and conditions. The strains were analysed for the presence of the following antibiotic resistance genes - aadA, bla $a_{P S E}$, bla $_{A M P} C$, bla $_{I M P}$ and tetC encoding aminoglycosides, betalactamases, metallo-beta-lactamases (MBL) and tetracylines resistance respectively. On screening the isolates for the presence of class 1 integrons, $50 / 60(83.3 \%)$ clinical isolates and 46/60 (76.7\%) environmental isolates showed positive results $(P>0.05)$. In both clinical and environmental isolates, the highest occurring resistance genes were bla $_{A M P} C$ and tetC (encoding beta-lactamases and tetracylines respectively), while the least was observed in $b l a_{I M P}$ (encoding metallo-beta-lactamases). In comparison, there was high significance difference (at $\mathrm{P}<0.01$ significance level) in the resistance gene bla $a_{P S}$ between the clinical and environmental strains. The high prevalence of these resistance genes is a great threat in the treatment of Pseudomonas infections.
\end{abstract}

\section{DOI: https://dx.doi.org/10.4314/jasem.v24i4.14}

Copyright: Copyright $(\mathcal{O} 2020$ Isichei-Ukah and Enabulele. This is an open access article distributed under the Creative Commons Attribution License (CCL), which permits unrestricted use, distribution, and reproduction in any medium, provided the original work is properly cited.

Dates: Received: 15 February 2020; Revised: 7 March 2020; Accepted: 28 March 2020

Keywords: Pseudomonas aeruginosa, Resistance genes, Integrons, Beta-lactamases.

Pseudomonas aeruginosa is one of the most clinically significant bacteria. It is highly implicated in nosocomial infections in immuno-compromised patients. It has a natural resistance to $\beta$-lactams, including broad-spectrum cephalosporins, quinolones, chloramphenicol and tetracyclines, mainly due to their cell wall having low permeability. In addition to this mechanism, they possess inducible cephalosporinase, active efflux and poor affinity for the target (DNA gyrase) (Brown and Izundu, 2004). However, acquired extended spectrum $\beta$-lactamases (ESBL) and metallo$\beta$-lactamases (MBL) mediated resistance is important emerging resistance mechanisms in $P$. aeruginosa (Lambert, 2002). These mechanisms thwart the use the treatment of infections using currently available drugs and anti-pseudomonal antibiotics.

The rapid dissemination of antibiotic resistance genes among bacterial isolates is an increasing problem in infectious disease. This organism has a high propensity to develop, acquire or transfer antimicrobial resistance genes (Gales et al., 2001). This phenomenon is associated with increased rates of morbidity, mortality and high cost of treatment
(Kohler et al., 2001). Many resistance genes are present as gene cassettes within integrons, which may themselves be located on transmissible plasmid and transposon (Recchia and Hall, 1995).

Class I integrons (int-1) contribute to the spread of antimicrobial resistance genes and have been found in Enterobacteriaceae and other Gram-negative bacteria (Fluit and Schmitz, 1999), but they have also been found in a few Gram-positive bacteria. This study was carried out to determine the prevalence and distribution of class 1 integrons and relevant antibiotic resistance genes among the different Pseudomonas aeruginosa strains from clinical and environmental settings.

\section{MATERIALS AND METHODS}

Bacterial Isolates: One hundred and twenty (120) isolates of $P$. aeruginosa from diverse clinical and environmental sources were employed in this study. The clinical isolates $(n=60)$ were obtained from government-owned and private-owned hospitals in Benin City, Edo State, Nigeria. The isolates were obtained from patient's sputum, wounds, urine, blood, 
infected ears and eyes. The environmental isolates ( $\mathrm{n}$ $=60$ ) were from hospital environment, abattoirs and dump sites around Benin City. Standard microbiological methods were used to identify the isolates, as previously described by Isichei-Ukah and Enabulele (2018).

Isolation of Genomic DNA: Genomic DNA extraction was carried out by the method used by Odumosu et al. (2013). Briefly, the $P$. aeruginosa isolates were inoculated into $2 \mathrm{ml}$ of tryptic soy broth and incubated overnight at $37^{\circ} \mathrm{C}$. The bacterial cells were harvested by centrifugation at $8,000 \times \mathrm{g}$ for $5 \mathrm{~min}$ and the supernatant was completely removed using sterile Pasteur pipette. The pellet was re-suspended in $500 \mu 1$ of Tris EDTA (TE) buffer. The cells were lysed by boiling for $10 \mathrm{~min}$ in a water bath, cooled on ice, and centrifuged at $14,000 \times \mathrm{g}$ for $5 \mathrm{~min}$ to remove any cell debris before it was stored at $-20^{\circ} \mathrm{C}$. Aliquots of $2 \mu 1$ of the template DNA were used for polymerase chain reaction $(\mathrm{PCR})$.

Molecular Identification of Pseudomonas aeruginosa: Polymerase chain reaction (PCR) was used to confirm the identities of Pseudomonas aeruginosa using species-specific primers set. The primers used were: pa722F (5'-GGCGTGGGTGTG GAAGTC-3') and pa899R (5'-TGGTGGCGATCTTGAACTTCTT-3') amplicon size of $199 \mathrm{bp}$, which detects 16S rRNA for $P$. aeruginosa and PCR conditions (Lutz and Lee, 2011). Pseudomonas aeruginosa reference strain (ATCC 27853) was used as positive control.

Polymerase Chain Reaction for Detection of Class 1 Integrons: Polymerase chain reaction (PCR) was used to detect the presence of class 1 integrons in the Pseudomonas aeruginosa strains using the specific primer pairs: int 1-F (5'AAAACCGCCACTGCGCCGTTA3') and int 1-R (3'GAAGACGGCTGCACTGAACG5'). The PCR conditions were: initial denaturation at $94^{\circ} \mathrm{C}$ for 12 min, 1 min of denaturation at $94^{\circ} \mathrm{C}, 1 \mathrm{~min}$ of annealing at $55^{\circ} \mathrm{C}$ and $5 \mathrm{~min}$ of extension at $72^{\circ} \mathrm{C}$ for a total of 35 cycles (Fonseca et al. (2005). All reactions were set in $25 \mu \mathrm{l}$ volume of reaction buffer containing 0.05 unit $/ \mu \mathrm{l}$ Taq polymerase as directed by the manufacturer (Fermentas Life Sciences, USA). Electrophoresis of amplicons were performed with 2 $\%$ agarose gel containing $0.5 \mathrm{mg} / \mathrm{L}$ Ethidium Bromide (EtBr) (Merck, SA) for $1 \mathrm{~h}$ at $100 \mathrm{~V}$ in $0.5 \times \mathrm{TAE}$ buffer $(40 \mathrm{mM}$ Tris- $\mathrm{HCl}, 20 \mathrm{mM}$ Na-acetate, $1 \mathrm{mM}$ EDTA, $\mathrm{pH}$ 8.5) and visualized under an ultra-violet transilluminator.

Polymerase Chain Reaction for Detection of Antibiotic Resistant Genes: Polymerase chain reaction (PCR) was used to detect the presence of antibiotic resistance genes on the isolates. The resistances genes detected were aadA (encoding aminoglycosides), bla $a_{P S E}$ (encoding beta-lactamase), bla $a_{A M P} C$ (encoding betalactamase), $\operatorname{bla}_{I M P}$ (encoding methallo-beta-lactamase) and tet $\mathrm{C}$ (encoding tetracyclines). The set of primers and PCR conditions used were earlier described by researchers: aadA (Fonseca et al., 2005), bla PSE $_{\text {(Bert }}$ et al., 2002), bla $a_{A M P} C$ (Yang et al., 2008), bla IMP (Fonseca et al., 2005) and tetC (Agerso and Sandvang, 2005). The electrophoresis of the PCR reaction was carried out using $2 \%(\mathrm{w} / \mathrm{v})$ agarose gel in $0.5 \times \mathrm{TBE}$ buffer applying a voltage of $100 \mathrm{~V}$ for $45 \mathrm{~min}$ and stained with ethidium bromide. Molecular weight marker of $100 \mathrm{bp}$ was used as gene DNA Ladder. After electrophoresis, gel image was performed using imaging system UV transilluminator.

Statistical Analysis: All data were tabulated and then processed using SPSS, version 21.0. The distribution of resistance genes between clinical and environmental isolates was compared using the chisquare test. A $P$-value $<0.05$ was considered statistically significant (Ogbeibu, 2005).

\section{RESULTS AND DISCUSSION}

Prevalence of Class 1 Integrons: By agarose gel electrophoresis PCR assay, clinical and environmental isolates were screened for the presence of class 1 integrons using int 1 primer. Of the 60 clinical isolates tested, $50(83.3 \%)$ were positive for class 1 integrons. For the environmental isolates $(n=60), 46(76.7 \%)$ isolates were positive (Table 1). There was no significant difference $(\mathrm{P}>0.05)$ in prevalence of class 1 integrons for clinical and environmental isolates.

\begin{tabular}{|c|c|c|c|}
\hline $\begin{array}{l}\text { Integrase } \\
\text { gene }\end{array}$ & Source & $\begin{array}{l}\text { Prevalence } \\
\mathrm{n}=60\end{array}$ & $\begin{array}{l}\text { \% } \\
\text { Occurrence }\end{array}$ \\
\hline int1 & Clinical & 50 & 83.3 \\
\hline int 1 & Environmental & 46 & 76.7 \\
\hline
\end{tabular}

Class 1 integrons play an important role in transferring antibiotics resistance. Its prevalence is alarming for infections caused by this bacterium. The present study investigating the existence of class 1 integrons revealed $83.3 \%$ and $76.7 \%$ for clinical and environmental isolates respectively (Table 1). This is higher than previous reports of 57.4\% from Southwest Nigeria (Odumosu et al., 2013). Other researchers had previously reported incidence rates of $41.5 \%$ from Brazil (Fonseca et al., 2005), 45.8\% from China (Xu et al., 2009), and 56.3\% from Iran (Yousefi et al., 2010). 
In Africa, class 1 integrons had previously been reported in clinical isolates of $P$. aeruginosa. Labuschagne et al. (2008) reported bla $a_{\mathrm{GES}-5}$ and $b l a_{\mathrm{GES}-}$ ${ }_{5}$-like genes as part of the variable region of class 1 integrons, occurring in three clinical $P$. aeruginosa isolates from South Africa. Another study reported class 1 integron containing bla $a_{\mathrm{VIM}-2}, a a c A 7$ and $a a c A 4$, as well as $a a d B$ and $\operatorname{arr} 6$, a novel rifampin resistance gene among 35 clonally related $P$. aeruginos $a$ isolated from a hospital in Tunisia (Hammami et al., 2010).

Although there was no significant difference between clinical and environmental isolates $(\mathrm{P}>0.05)$ in this study, the clinical isolates had a higher prevalence of are strongly associated with multiple drug resistance and are frequently detected among clinical isolates of P. aeruginosa (Martinez et al., 2012). The prevalence of class 1 integrons in the isolates of $P$. aeruginosa from this region is of great concern because these genetic elements are highly stable among resistant pathogens, and also capable of easy spread and capture of other multidrug resistance gene cassettes which may lead to increase in resistance to broad spectrum antibiotics (Tenover, 2006).

Prevalence of Resistance Genes: The percentage occurrence of the resistance genes in the clinical isolates were shown (Table 2). Among the five resistance genes, $b l a_{A M P}$ had the highest prevalence of 95.0\%; and the least was in $\operatorname{bla}_{I M P}(3.3 \%)$. There was very high significant difference in prevalence among resistance genes in the clinical isolates $(\mathrm{P}<0.001)$.

For the environmental isolates, $b l a_{A M P}$ also had the highest prevalence of $98.3 \%$. Resistance gene, bla IMP $_{\text {, }}$ had the least prevalence of $5.0 \%$ (Table 3 ). There was very high significant difference in prevalence among class 1 integrons. This suggests that class 1 integrons

resistance genes in the environmental isolates $(\mathrm{P}<0.001)$.

The comparison of each of the antibiotic resistance genes between the clinical and environmental isolates are shown in Figure 1. There was no significant difference in prevalence between the clinical and environmental isolates $(\mathrm{P}>0.05)$ for all resistance genes, except for bla $a_{P S E}$ where there was high significant difference (at $\mathrm{P}<0.01$ ).

Table 2: Prevalence of Antibiotic Resistance Genes in Clinical Isolates of Pseudomonas aeruginosa.

\begin{tabular}{lll}
\hline $\begin{array}{l}\text { Resistance } \\
\text { Genes }\end{array}$ & Antibiotic Class & $\begin{array}{l}\text { Occurrence } \\
(\mathbf{\%}) \mathbf{n}=\mathbf{6 0}\end{array}$ \\
\hline $\boldsymbol{a a d A}$ & Aminoglycosides & $12(20.0)$ \\
$\boldsymbol{b l a}_{P S E}$ & Beta-lactams & $28(46.7)$ \\
bla $_{A M P} \boldsymbol{C}$ & Beta-lactams & $57(95.0)$ \\
$\boldsymbol{b l a}_{\boldsymbol{I M P}}$ & Carbapenems & $2(3.3)$ \\
$\boldsymbol{t e t C}$ & Tetracycline & $48(80.0)$ \\
\hline
\end{tabular}

Table 3: Prevalence of Antibiotic Resistance Genes in Environmental Isolates of Pseudomonas aeruginosa

\begin{tabular}{lll}
\hline $\begin{array}{l}\text { Resistance } \\
\text { Genes }\end{array}$ & Antibiotic Class & $\begin{array}{l}\text { Occurrence } \\
(\%) \mathbf{n}=\mathbf{6 0}\end{array}$ \\
\hline $\boldsymbol{a a d \boldsymbol { A }}$ & Aminoglycosides & $10(16.7)$ \\
bla $_{P S E}$ & Beta-lactams & $13(21.7)$ \\
$\boldsymbol{b l a}_{\boldsymbol{A M P}} \boldsymbol{C}$ & Beta-lactams & $59(98.3)$ \\
$\boldsymbol{b l a}_{\boldsymbol{I M P}}$ & Carbapenems & $3(5.0)$ \\
$\boldsymbol{t e t C}$ & Tetracycline & $46(76.7)$ \\
\hline
\end{tabular}

From the results (Tables 2 and 3), the prevalence of the target resistance genes were observed. This finding correlated with the works of Igbinosa and Obuekwe (2014); who detected the presence of some resistance genes to be $\operatorname{bla}_{I M P}(14.7 \%)$, bla $_{A M P} C(14.7 \%)$, and tetC $(5.8 \%)$ in $P$. aeruginosa isolates from abattoir environment around this region (Benin City, Nigeria). The presence of aadA genes (encoding aminoglycosides resistance) was $20 \%$ and $16.7 \%$ for clinical and environmental isolates respectively. There was no significant difference between clinical and environmental isolates $(\mathrm{P}>0.05)$.

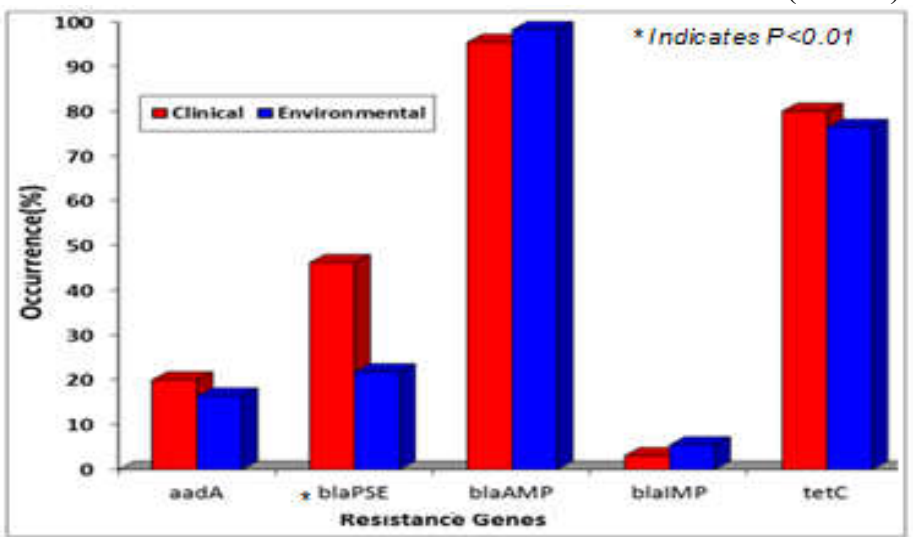

Fig 1: Prevalence of Antibiotic Resistance Genes in Clinical and Environmental Isolates of Pseudomonas aeruginosa From this study, the prevalence of bla $_{A M P} C$ (encoding beta-lactam resistance gene) was $95 \%$ and $98.3 \%$ for clinical and environmental isolates respectively. There was no significant difference between clinical and 
environmental isolates $(\mathrm{P}>0.05)$. But for bla $_{P S E}$, also encoding beta-lactam resistance, had prevalence of $46.7 \%$ and $21.7 \%$ for clinical and environmental isolates respectively. There was high significant difference between clinical and environmental isolates $(\mathrm{P}<0.01)$. The clinical isolates had a higher prevalence. This correlates with the works of Bert et al. (2002) who detected $62.5 \%$ of bla PSE $_{\text {resistance genes in }}$ clinical isolates in France. The presence of bla $a_{I M P}$ genes (encoding metallo- $\beta$-lactam or carbapenem resistance genes) was $3.3 \%$ and $5 \%$ for clinical and environmental isolates respectively. There was no significant difference between clinical and environmental isolates $(\mathrm{P}>0.05)$. Among the other

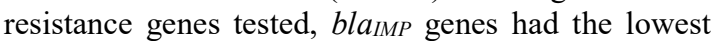
prevalence. The existence of metallo- $\beta$-lactamases and extended-spectrum $\beta$-lactamase-producing strains exhibiting resistance to most $\beta$-lactams antimicrobial agents greatly complicate the clinical management of patients infected with such multi-drug-resistant strains (Moreira et al. 2002; Pagani et al. 2002). The prevalence of tetC gene (encoding tetracycline resistance) in this study was $80 \%$ and $76.7 \%$ for clinical and environmental isolates respectively. There was no significant difference between clinical and environmental isolates $(\mathrm{P}>0.05)$. This is in contrast with the work of Igbinosa and Obuekwe (2014), which had a prevalence of $5.8 \%$ in environmental isolates in this region. The presence of this resistance genes in the isolates could be attributed to the fact that this antibiotic is used indiscriminately in our environment and could also be as a result of the isolates possession of an intrinsic and acquired resistance mechanism caused mainly by an active efflux system, which efficiently expels the compound from the cell (Kohler et al., 2001).

Conclusion: The high prevalence of class 1 integrons and resistance genes is really alarming and this can be great threat in the control and treatment of pseudomonal infections. However, this can result in increased length of hospitalization and mortality. Therefore, practical steps should be taken in the proper use of antibiotics in both clinical and environmental settings.

\section{REFERENCES}

Agerso, Y; Sandvang, D (2005). Class 1 integrons and tetracycline resistance genes in Alcaligenes, Arthrobacter and Pseudomonas spp. isolated from pigsites and manured soil. Applied and Environmental Microbiology 71(12):7941-7947.

Bert, F; Branger, C; Lambert-Zechovsky, N (2002). Identification of PSE and OXA $\beta$-lactamase genes in Pseudomonas aeruginosa using PCRrestriction fragment length polymorphism. Journal of Antimicrobial Chemotherapy 50:1118.

Brown, PD; Izundu, A (2004). Antibiotic resistance in clinical isolates of Pseudomonas aeruginosa in Jamaica. Revista Panamericana de Salud Publica 16(2):125-130.

Fluit, AC; Schmitz, FJ (1999). Class 1 integrons, gene cassettes, mobility, and epidemiology. European Journal of Clinical Microbiology and Infectious Diseases 18:761-770

Fonseca, EL; Vieira, VV; Cipriano, R; Vicente, ACP (2005). Class 1 integrons in Pseudomonas aeruginosa isolates from clinical settings in Amazon region, Brazil. FEMS Immunology and Medical Microbiology 44:303-309.

Gales, AC; Jones, RN; Turnidge, J; Rennie, R; Ramphal, R (2001). Characterization of Pseudomonas aeruginosa isolates: occurrence rates, antimicrobial susceptibility patterns, and molecular typing in the global SENTRY Antimicrobial Surveillance Program, 1997-1999. Clinical Infectious Diseases 32:146-155.

Hammami, S; Gautier, V; Ghozzi, R; Da Costa, A; Ben-Redjeb, S; Arlet, G (2010). Diversity in VIM-2-encoding class 1 integrons and occasional blaSHV2a carriage in isolates of a persistent, multidrug-resistant Pseudomonas aeruginosa clone from Tunis. Clinical Microbiology and Infection 16: 189-193.

Igbinosa, EO; Obuekwe, IS (2014). Evaluation of antibiotic resistant gene in abattoir environment. Journal of Applied Science and Environmental Management 18(2): 165-170.

Isichei-Ukah, OB; Enabulele, OI (2018). Prevalence and antimicrobial resistance of Pseudomonas aeruginosa recovered from environmental and clinical sources in Benin City, Nigeria. Ife Journal of Science 20(3): 547-555.

Kohler, T; Delden, CV; Curty, LK; Hamrehpour, MM; Pechere, JC (2001). Over expression of the MexEF-OprN multi-drug efflux system affects cell-to-cell signalling in Pseudomonas aeruginosa. Journal of Bacteriology 183: 52135222 .

Labuschagne, CJ; Weldhagen, GF; Ehlers, MM; Dove, MG (2008). Emergence of class 1 integron- 
associated GES-5 and GES-5-like extendedspectrum betalactamases in clinical isolates of Pseudomonas aeruginosa in South Africa. International Journal Antimicrobial Agents 31: 527-530.

Lambert, PA (2002). Mechanisms of antibiotic resistance in Pseudomonas aeruginosa. Journal of the Royal Society Medicine 95:22-26.

Lutz, JK; Lee, J (2011). Prevalence and antimicrobial resistance of Pseudomonas aeruginosa in swimming pools and hot tubs. International Journal of Environmental Research and Public Health 8(2):554-564.

Martinez, E; Marquez, C; Ingold, A; Merlino, J; Djordjevic, SP; Stokes, HW; Chowdhurya, PR (2012). Diverse mobilized class 1 integrons are common in the chromosomes of pathogenic Pseudomonas aeruginosa clinical isolates. Antimicrobial Agents and Chemotherapy 56: 2169-2172.

Moreira, BM; Pellegrino, FLPC; Teixeira, LM (2002). Occurrence of multi-drug-resistance Pseudomonas aeruginosa clone in different hospitals in Rio de Janeiro, Brazil. J. Clinical Microbiol. 40: 2420-2424.

Odumosu, BT; Adeniyi, BA; Chandra, R (2013). Analysis of integrons and associated gene cassettes in clinical isolates of multidrug resistant Pseudomonas aeruginosa from Southwest Nigeria. Annals of Clinical Microbiology and Antimicrobials 12: 1-7.
Ogbeibu, AE (2005). Biostatistics: A Practical Approach to Research and Data Handling. Mindex Publishing Company Limited, Benin City, Nigeria.

Pagani, L; Migliavacca, R; Docquier, JD (2002). Simple microdilution test for detection of metallo$\beta$-lactamase production in Pseudomonas aeruginosa. Journal of Clinical Microbiology 40(11): 4388-4390.

Recchia, GD; Hall, RM (1995). Gene cassettes: a new class of mobile element. Microbiology 141: 30153027.

Tenover, FC (2006). Mechanisms of antimicrobial resistance in bacteria. American Journal of Medicine 119:3-10.

Xu, Z; Li, L; Shirtliff, ME; Alam, MJ; Yamasaki, S; Shi, L (2009). Occurrence and characteristics of class 1 and 2 integrons in Pseudomonas aeruginosa isolates from patients in Southern China. Journal of Clinical Microbiology 47:230234.

Yousefi, S; Nahaei, MR; Farajnia, S; Ghojazadeh, M; Akhi, MT; Sharifi, Y; Milani, M; Ghotaslou, R (2010). Class 1 integron and imipenem resistance in clinical isolates of Pseudomonas aeruginosa: prevalence and antibiotic susceptibility. Iranian Journal of Microbiology 2:113-119.

Yang, CH; Lee, S; Su, P; Yang, CS; Chuang, L (2008). Genotype and antibiotic susceptibility patterns of drug-resistant Pseudomonas aeruginosa and Acinetobacter baumannii isolates in Taiwan. Microbial Drug Resistance 14:281-288. 